This is an electronic reprint of the original article. This reprint may differ from the original in pagination and typographic detail.

Author(s): Salminen, Jenni; Hännikäinen, Maritta; Poikonen, Pirjo-Liisa; Rasku-Puttonen, Helena

Title: $\quad$ A Descriptive Case Analysis of Instructional Teaching Practices in Finnish Preschool Classrooms

Year: $\quad 2013$

Version:

Please cite the original version:

Salminen, J., Hännikäinen, M., Poikonen, P.-L., \& Rasku-Puttonen, H. (2013). A Descriptive Case Analysis of Instructional Teaching Practices in Finnish Preschool Classrooms. Journal of Research in Childhood Education, 27(2), 127-152. https://doi.org/10.1080/02568543.2013.767289

All material supplied via JYX is protected by copyright and other intellectual property rights, and duplication or sale of all or part of any of the repository collections is not permitted, except that material may be duplicated by you for your research use or educational purposes in electronic or print form. You must obtain permission for any other use. Electronic or print copies may not be offered, whether for sale or otherwise to anyone who is not an authorised user. 
INSTRUCTIONAL TEACHING PRACTICES IN PRESCHOOLS

A Descriptive Case A nalysis of Instructional Teaching Practices in Finnish Preschool Classrooms

aj enni Salminen, ${ }^{\mathrm{a} M}$ aritta Hännikäinen, ${ }^{\mathrm{P}}$ Pirjo-Liisa Poikonen, \& ${ }^{\mathrm{b}} \mathrm{H}$ elena Rasku-Puttonen

${ }^{a}$ D epartment of E ducation, U niversity of J yväskylä, Finland; 'D epartment of Teacher E ducation, University of J yväskylä, Finland

This study was carried out in the Center of Excellence in Learning and M otivation Research financed by the A cademy of Finland (N 0. 213486 for 2006-2011) and other grants from the same funding agency (N o. 213353 for 2005-2008, and No. 125811 for 2008-2009). The fourth author was also funded by the A cademy of Finland (N o. 130707). The data were collected as part of the First Steps follow-up study organized by the Center of Excellence. The first author gratefully acknowledges the personal support and effort invested by the following individuals in the data gathering for this research project: Dr. M arja-K ristiina Lerkkanen, A nna-M aija Poikkeus (PhD), and Dr. M artti Siekkinen. The work presented herein was conducted in partial fulfillment of the first author's doctoral dissertation.

Correspondence: J enni Salminen, Department of Education, U niversity of J yväskylä, P.O. B ox 35, 40014 J yväskylä, Finland; tel: +(358) 40-776-0487; fax: +(358) 14-260-1761; e-mail: jenni.e.salminen@jyu.fi. 


\begin{abstract}
The present study aimed to examine the diversity of teaching practices and to illuminate the qualitative variety of instructional teaching practices among preschool teachers. Further, teachers' self-rated educational goals were explored to complement the multifaceted nature of preschool teachers' instructional teaching practices. The study was carried out as a case study. The cases were used to describe the qualitative variety of Finnish preschool teachers' instructional practices in authentic classroom situations among groups of six-year-old children. Our previous study (Salminen et al., 2010) revealed four distinct latent profiles of teaching practices in preschool classrooms based on 49 observed preschool teachers, using the Classroom A ssessment Scoring System (CLA SS, Pre-K ; Pianta, LaParo, \& Hamre, 2008). In the present study, the cases represent each of the latent profiles. B ased on the qualitative content analysis, we could elucidate the variety of observed instructional practices and identify how they varied among the teachers. The observed instructional practices occurred in different combinations, creating ample opportunities for learning in preschool classrooms. It was also discovered that teachers' selfreported educational goals reflected their observed practices quite well. The findings suggest pedagogical implications for the development of preschool education and teacher training.
\end{abstract}

Keywords: CLASS, instructional teaching practices, classroom observations, preschool 
INSTRUCTIONAL TEACHING PRACTICES IN PRESCHOOLS

\section{A Descriptive Case A nalysis of Instructional Teaching Practices in Finnish Preschool Classrooms}

Children spend a considerable amount of time in educational settings in which they share varying interpersonal interactions even before they start their formal education in primary school (H offerth \& Sandberg, 2001). It has been suggested that especially teachers' high quality practices and their reciprocal interactions with children enhance learning and development (e.g., Birch \& Ladd, 1997, 1998; Hännikäinen \& Rasku-Puttonen, 2010). Teachers develop teaching practices in their own personal way and this appears to result in relatively unique educational experiences differing from classroom to classroom (e.g., B ohn, Roehrig, \& Pressley, 2004). In the U nited States, the Classroom A ssessment Scoring System (CLASS; Pianta, LaParo, \& Hamre, 2008) is widely used as a measure of teaching practices and classroom quality in a variety of educational contexts. Previous studies using the CLASS have yielded large-scale generalizable results on practices improving classroom quality (Hamre, Pianta, M ashburn, \& Downer, 2007; J ustice, M ashburn, Hamre, \& Pianta, 2008). It is widely acknowledged that a higher quality of teaching further enhances children's academic and social development (Howes et al., 2008; M ashburn et al., 2008), peer relations (Peisner-Feinberg et al., 2001), and children's motivation to learn (Pakarinen, K iuru, et al., 2010).

The recent CLASS profiling studies have suggested that high quality educational settings and practices are not evenly distributed across classrooms of different age groups in the U.S.A. (Curby, LoC asale-Crouch, et al., 2009; LoC asale-Crouch et al., 2007). A profiling study by Salminen et al. (in press), on the other hand, suggested that the provision of high-quality teaching practices, and thus also learning opportunities for children, were quite evenly distributed throughout the Finnish preschool educational system. The profiles seemed to fairly accurately represent the homogeneity of the 
INSTRUCTIONAL TEACHING PRACTICES IN PRESCHOOLS

education provided in preschool classrooms throughout the country. Furthermore, despite the national curriculum (Core Curriculum for Preschool Education, 2000) in Finland, teachers possess greater freedom to determine the structure and content of the actual classroom teaching than their counterparts in many other countries (Office for Standards of Education, 2003), which leads to the evolution of different yet highly effective teaching practices within every classroom. Nonetheless, a previous study by Salminen et al. (in press) has revealed that there is some variety among teaching practices in terms of instructional support in Finnish preschool classrooms. Similar findings have also been reported in several U.S. studies (e.g., Hamre et al., 2007; LaParo, Pianta, \& Stuhlman, 2004; LaParo, Rimm-K aufman, \& Pianta, 2006), suggesting that the provision of high-quality instructional support for children is not al ways evenly distributed across classrooms. This is problematic as several studies have emphasized the importance of instructional support for children's academic and social development (e.g., Curby, Rimm-K aufman, \& Ponitz, 2009; Eccles \& Roeser, 1999; Hamre \& Pianta, 2005; Howes et al., 2008).

We might assume that teachers' instructional practices differ according to children's age. In the present study the sample comprises six-year-old Finnish preschoolers and their teachers, whereas the children's age usually varies from 3 to 8 years in the CLASS studies conducted in the U nited States. Even though the Finnish preschoolers are indeed the same age as the first graders in the U.S.A., the education and teachers' practices in Finnish preschool classrooms are more of a mixture similar to those in the kindergarten and primary classrooms in the United States (i.e., play and playfulness alongside of academic skill development have an important role in Finnish preschools) (e.g., Core Curriculum for Preschool Education, 2000; Howes et al., 2008; LaParo et al., 2009; W hartonM CD onald,1998). This creates an interesting backdrop for exploring the practices of Finnish preschool teachers more thoroughly. 
INSTRUCTIONAL TEACHING PRACTICES IN PRESCHOOLS

A substantial amount of research using the CLASS procedure has shown that there is variety in the distribution of high-quality teaching practices (e.g., LaParo, Pianta, \& Hamre, 2004; LoC asaleCrouch et al., 2007), and such studies have been conducted with large samples and interpreted on the basis of sample means. However, comparing the means of teachers' observed practices is not always a sufficient indicator of the teaching-learning procecces at the classroom level: Teachers can produce good results and high quality teaching through varying practices, and even highly similarly rated teachers can produce very different teaching practices. Thus far, the qualitative studies on teaching practices have been scarce both in international and Finnish contexts (e.g., B ohn et al., 2004;

K orkeamäki \& Goman, 2002; W harton-M cD onald, Pressley, \& Hampston, 1998). The variety in observed instructional practices in Finnish preschool classrooms (Salminen et al., in press; Pakarinen, Lerkkanen, et al., 2010) calls for more detailed research concerning individual teachers and the fine differences in their actual instructional practices on an individual level.

Further, previous studies have found congruency between teachers' self-reported goals and their observed classroom practices: It seems that teachers' goals and beliefs predict or direct their actual work with children in an even more powerful way than their work experience (LaParo et al., 2009; Pajares, 1992). A t best, teachers' self-reports can be used to complement the versatile aggregate of teachers' practices in their actual work with children. Despite the clear usefulness of these assessments, they have not been taken into account in the more recent studies utilizing, for instance, the CLASS framework (e.g., Curby et al., 2009; LoC asale-Crouch et al., 2007).

W ith our present research, we seek to contribute to the discussions on the development of the quality of preschool classrooms by having conducted a qualitative case analysis to examine the diversity of teaching practices and to illuminate the qualitative variety of instructional teaching practices among preschool teachers. Furthermore, teachers' self-rated educational goals are explored 
INSTRUCTIONAL TEACHING PRACTICES IN PRESCHOOLS

to complement the multifaceted nature of preschool teachers' instructional teaching practices. Information derived from case studies such as this one yields knowledge on the processes of teaching beyond the numeric CLASS ratings and can be used in supporting teachers' awareness of the importance of their practices as well as their professional development.

\section{The Importance of T eaching Practices}

Through their professional role, teachers are key players in determining what kinds of learning opportunities children are provided with (e.g., Hännikäinen, de J ong, \& Rubinstein Reich, 1997; Sylva et al., 2007). How teachers teach and instruct children is not insignificant; quite the contrary, teachers' practices contribute to children's development in various ways. In addition, teachers' interactions with children and the quality of their practices may affect how the children experience learning not only in their early years but also later on in their school career (Curby, Rimm-K aufman, et al., 2009).

\section{The CLASS Framework}

It has been suggested by several authors (e.g., Eccles \& Roeser, 1999; Hamre et al., 2007) that teacher-child interactions and teachers' practices can be categorized according to three broader domains (i.e., emotional support, organizational support, and instructional support) and that each of these domains provides unique support for children's different developmental outcomes. The Classroom A ssessment Scoring System (CLASS; Pianta et al., 2008) al so relies on these three conceptual domains in capturing the elements of the teacher-child interactions and teachers' practices in classrooms according to different age groups. B esides in research by the CLASS developers, these three domains have also been identified by several other studies. For example, Pressley and colleagues (2003) divide effective teaching strategies into creating a motivational atmosphere, 
INSTRUCTIONAL TEACHING PRACTICES IN PRESCHOOLS

classroom management, and curricular and instructional decisions. Similarly, Eccles and Roeser (1999) emphasize the importance of social, organizational and instructional processes in classrooms. Further, B rophy (1999) describes principles of effective teaching to include supportive classroom climate, opportunities to learn and thoughtful discourse. In our study, the teachers' practices under the domain of instructional support are of special interest.

\section{Instructional Support and its C ontribution to Children's L earning.}

Instructional support implies the practices through which teachers implement learning activities to effectively support cognitive and academic development (Pianta \& Hamre, 2009). The differences in these types of practices create significantly different environments of support in the classroom, for example, for the development of children's literacy skills (C unningham, 2008). The theoretical foundation of the instructional support domain in the CLASS framework draws primarily from studies on children's cognitive development (e.g., V ygotsky, 1991; W harton-M cD onald et al., 1998). These theories emphasize, for example, the importance of scaffolding, cognitive restructuring of one's knowledge and understanding (Davis \& M iyake, 2004; V ygotsky, 1991), and the awareness of one's thinking processes (W illiams, Blythe, \& White, 2002).

Instructional teaching practices in preschool classrooms should include, for instance, teachers' support for developing children's higher order thinking skills (not relying solely on rote learning), the provision of constructive feedback, and rich language stimulation (Curby, Rimm-K aufman, et al., 2009; Pressley, Rankin, \& Y okoi, 1996). In studies on children aged 3 to 5 years, a high level of instructional support is associated with gains in language and mathematical skills (Howes et al., 2008; M ashburn et al., 2008; Pianta \& Hadden, 2008), as well as in-task behaviors having been observed more frequently in such classrooms (Pianta, LaParo, Payne, Cox, \& B radley, 2002). It has been suggested that teachers' provision of constructivist instructional exercises allowing preschool 
INSTRUCTIONAL TEACHING PRACTICES IN PRESCHOOLS

children's cooperation result in better language awareness (i.e., letter knowledge, word recognition, phonological awareness, and writing skills) than is the case for the more didactic drilling of basic skills (K orkeamäki \& Goman, 2002). Further, teachers' use of scaffolding, questioning, and modeling activities may stimulate children's cognitive and linguistic development (Sylva et al., 2007).

Previous studies on children in primary schools have shown that teachers' instructional practices when focused on and directed toward the scaffolding of learning and thinking processes, significantly contribute to children's academic performance (Curby, Rimm-K aufman, \& Ponitz, 2009). It has also been reported that practices which primarily rely on the teacher's role and use of rhetoric do not effectively support the development of children's own thinking (W ebb, Nemer, \& Ing, 2006). In addition, instructional practices have been found to be more effective when feedback takes children's performance into account and when the productive time for learning is maximized. When effective feedback is not used in teaching, it is unclear whether or not interactions provide experiences that truly promote understanding (Burnett, 2002; NICHD/ECCRN, 2002; Perry, Donohue, $\&$ W einstein, 2007).

B ohn et al. (2004) compared the first days of school in classrooms of effective vs. ineffective primary school teachers and described, among other aspects, the teachers' instructional practices in these classrooms. The more effective teachers seemed to be more enthusiastic in providing tasks for children and discussing and giving hints regarding the upcoming tasks. These teachers also expressed higher academic expectations of the children compared to the teachers in the more inefficient classrooms. W harton-M cD onald et al. (1998) compared nine primary grade teachers' literacy instruction (i.e., teachers' practices and child outcomes). The teachers of those children who demonstrated the highest levels of student outcomes were described as using large amounts of scaffolding and encouragement, as well as integrating many goals in each lesson. Similar findings 
INSTRUCTIONAL TEACHING PRACTICES IN PRESCHOOLS

were reported in a study by W ebb et al. (2008), where teachers' use of strategic encouragement and eliciting elaboration were connected with the children having more efficient explanatory skills compard to others in their peer group. In the Finnish educational context, teachers have been observed to be highly devoted to supporting 6- to 7-year-old children's participation in joint activities and in providing support according to the children's academic needs and abilities, which tends to promote children's curiosity and motivation toward learning (Hännikäinen \& Rasku-Puttonen, 2010). Thus far, we have merely emphasized the role of teachers' practices in creating ample opportunities for children to learn in educational settings. In addition, it seems noteworthy to also consider teachers' education and work experience as an important background for producing teaching practices. N ext, we will deal with teachers' self-reported educational goals as these may guide teachers in producing different teaching practices.

\section{The Importance of Teachers' Self-R eported E ducational G oals}

Previous studies have suggested that there is no systematic link between teachers' background characteristics (e.g., education) and the quality of their teaching practices (Early et al., 2007;

W hitehurst, 2002). Interestingly, it seems that teachers' self-reported goals and aims are more precise predictors of their actual teaching practices and the quality of their teaching than their traditional background characteristics (LaParo et al., 2009; Stipek \& Byler, 1997) as teachers' attitudes and beliefs often direct their actual practices within the classroom (Pajares, 1992). When it comes to teachers' self-reported educational goals, it has been suggested that a high extent of enriching literacy activities can provide a high quality classroom environment supporting children's academic development. For example, Connor, M orrison and Slominski (2006) found that the amount and type of language and literacy activities observed in classrooms consisting of four-year-olds had a 
INSTRUCTIONAL TEACHING PRACTICES IN PRESCHOOLS

significant and systematic relation to the children's growth in their knowledge of the al phabet, letterword recognition and vocabulary skills.

\section{Aim and Research Questions}

This study was designed to contribute to the discussions on the development of the quality of preschool classrooms by analyzing preschool teachers' instructional teaching practices. The aim of our study was to examine the diversity of teaching practices and to illuminate the qualitative variety of instructional teaching practices among preschool teachers. Further, teachers' self-rated educational goals were explored to complement the multifaceted nature of preschool teachers' instructional teaching practices. A nswers were sought to the following research questions: (1) W hat kind of instructional teaching practices (i.e., thematic CLASS constructs of concept development, quality of feedback, and language modeling) do teachers use in preschool classrooms and what kind of qual itative variety is there among the teachers? (2) How do teachers define their educational goals and how are these related to their instructional teaching practices? (3) What are the similarities and differences in teachers' instructional teaching practices and educational goals?

\section{M ethod}

\section{Context of the Present Study}

This case study comprised a sample of Finnish teachers and the six-year-old preschoolers enrolled in their classrooms. Finland is one of the few countries where compulsory education starts in the year that the child turns seven years of age. B efore commencement of formal schooling, six-yearold children have a statutory right to receive preschool education free of charge for one year. $N$ early all (98\%) six-year-old Finnish children opt for preschool education (Rautanen, 2007).

The preschool educational system in Finland is organized into preschool classrooms within daycare centers and primary schools. The majority of preschool classrooms are located in the 
INSTRUCTIONAL TEACHING PRACTICES IN PRESCHOOLS

premises of daycare centers $(78 \%)$. In rural areas, it is more common for preschool education to be offered in the same premises as primary schooling, whereas in urban areas, preschool classrooms are generally located in day care centers. Parents tend to take their children to the preschool classroom nearest to their home. Irrespective of how preschool education is distributed, the legislation and the educational guidelines remain exactly the same, according to the Core Curriculum for Preschool Education (2000) which came into force in 2002.

According to the core curriculum, the role of preschool education is to provide all children with an equal opportunity to learn the basic skills needed for primary school, while supporting the children's own interests and motivation toward learning. In preschool, the focus is on introducing academic pre-skills to children through playful and developmentally appropriate activities and in collaboration with peers. The specific " content areas" (similar to academic subjects) are stipulated in the core curriculum. Accordingly, children are for instance introduced to letters and phonemes but not directly taught to read. Hence, the role of a less formal education also receives attention while particular emphasis is placed on social skills, being considerate to others, and being an ethical member of society (Core Curriculum for Pre-school Education, 2000).

Finnish preschool teachers typically have either a bachelor's degree (BA) in Early Childhood Education (kindergarten teachers) or a master's degree (M A) in E ducation (primary school teachers); as a kindergarten teacher, having at least a tertiary-level (college) education has become mandatory. Since 1995, all prospective kindergarten teachers have to complete a bachelor's degree at a university and these graduates mostly end up working in day care centers. Those teachers who teach six-year-old children in preschool classrooms located in primary schools typically have a master's degree (Classroom Teacher Education).

\section{Q uality Profiles of T eaching Practices}


INSTRUCTIONAL TEACHING PRACTICES IN PRESCHOOLS

Findings on the use of the CLASS in Finland (Pakarinen, Lerkkanen, et al., 2010) have provided support for the construct validity of the three-factor model and evidence for its concurrent validity through expected associations with teacher questionnaire items, as well as evidence for the reliability (high item and domain correlations as well as high inter-rater reliability) of the CLASS in an educational context where a relatively homogenous general education is provided for a whole age group. The quality of teaching practices in 49 preschool classrooms was rated using the Classroom A ssessment Scoring System (CLASS, Pre-K; Pianta et al., 2008). The CLASS is designed to measure the classroom level variables of ten dimensions in three domains: 1) E motional Support (Positive Climate, N egative Climate, Teacher Sensitivity, Regard for Student Perspectives); 2) Classroom Organization (Behavior M anagement, Productivity, Instructional Learning Formats); and 3) Instructional Support (Concept Development, Quality of Feedback, Language M odeling). Each of the ten dimensions is rated from 1 - 7 by two trained observers on two separate days, utilizing the behavioral markers provided by the CLASS manual (Pianta et al., 2008); scores 1 - 2 indicate a low level, scores 3 - 5 are mid-range, and scores 6 - 7 represent a high level in regard to each observed classroom dimension.

In the study by Salminen et al. (in press), four distinct teacher profiles were identified across nine CLASS dimensions (one dimension, Negative Climate, was excluded from the final model because of its poor discriminatory value, which was also noted in the previous Finnish CLASS validation study by Pakarinen, Lerkkanen, et al. 2010) within the three domains of emotional support, classroom organization, and instructional support. The profiles from which the cases of the current study were selected can be summed up as follows: Profile 1 - Highest Q uality (prevalence 53\%). Classrooms in this profile showed intermediate to high levels of emotional support, classroom organization and instructional support, and generally attained scores that were clearly higher for all 
INSTRUCTIONAL TEACHING PRACTICES IN PRESCHOOLS

three domains compared to the sample mean; the scores were nearly one standard deviation higher than the sample mean. Profile 2 - M edium E motional, O rganizational and Instructional Q uality (prevalence 29\%). Classrooms in this profile attained scores very close to the sample mean for all three domains. Profile 3 - M edium to Low Emotional and Instructional Quality, Medium Organizational Quality (prevalence 12\%). Classrooms in this profile attained scores that were approximately one standard deviation below the sample mean. How ever, the scores for the domain of classroom organization were of a relatively similar level as those for Profile 2. A nd finally, Profile 4 Lowest Q uality (prevalence 6\%). Classrooms in this profile showed, on average, low levels of emotional support, classroom organization, and instructional support, and attained scores that were clearly below the sample mean. The scores were generally 2 standard deviations bel ow the sample mean.

\section{C ase Study A pproach and Selection of Cases}

The case study approach was utilized for this study because this approach is generally characterized by the observation of phenomena in their natural settings, leading to a better understanding of their occurrence and variety $(Y$ in, 2003). The case study approach was an appropriate methodological choice since the study focused on exploring the practices of individual teachers in more depth; this study did not aim to yield highly generalizable results, nor to choose cases in order to represent their subgroups or to be considered as typical teachers with particular profiles, but rather to provide a deeper description and knowledge of preschool teachers' actual instructional practices (cf., Y in, 2003).

One teacher was chosen from each of the four profiles for case analysis based on the means of CLASS ratings in the domain of instructional support. In each case, a teacher whose CLASS rating was closest to the profile's mean was chosen. The four selected teachers' personal domain means (i.e., 
INSTRUCTIONAL TEACHING PRACTICES IN PRESCHOOLS

their means for the three dimensions within the domain of instructional support) are presented as follows with the domain means relating to each teacher profile (the original group of 49 teachers) provided in parentheses for comparison: Teacher $A=4.44(4.59)$, Teacher $B=3.5(3.65)$, Teacher $C$ $=3.21$ (3.24), and Teacher $D=2.19$ (1.99). We could have chosen the cases randomly by drawing lots, but we decided to choose the cases based on the solid foundation of structured observational measures and the resulting knowledge of the quality of the teaching practices. Since the teacher profiles were statistically differentiated (for details see Salminen et al., in press), we could also assure that the teacher cases differed according to their practices. M erriam (1998) has called this type of selection a "maximum variation sample" as it provides the widest possible range of characteristics and thus the maximum amount of variation possible between cases.

\section{Participants}

Teachers in profiles $A, B$, and $C$ had more teaching experience ( $M$ ode $=$ more than 15 years) compared to Teacher D in Profile 4 ( $M$ ode $=1$ to 5 years). The classrooms of Teachers B and D were located in a primary school, whereas the classrooms of the Teachers A and C were located in daycare centers. Group size and number of teaching personnel in the preschool groups varied accordingly; i.e., in the context of primary school facilities the teacher typically works alone and the group size may be relatively small (e.g., the classrooms of Teachers B and D both consisted of 7 preschool children), whereas in the context of daycare centers each group typically consists of a minimum personnel of two teachers and one trained assistant and the group size is larger (e.g., the classrooms of Teachers A and $\mathrm{C}$ consisted of 24 and 22 preschool children respectively). The age range of the children in the four classrooms was as follows: Classroom of Teacher $A=68-79$ months; Teacher $B=71-78$ months, Teacher $C=68-76$ months, and Teacher $D=69-79$ months. A Il of the classrooms contained 
INSTRUCTIONAL TEACHING PRACTICES IN PRESCHOOLS

typical preschool materials and followed the educational guidelines determined in the national curriculum (Core Curriculum for Preschool Education, 2000).

\section{M easures and Procedures}

O bservation. B efore starting the observations, the observers (17 female university students from the fields of Early Childhood Education, Classroom Teacher Education and Psychology) were carefully trained in accordance with the CLASS manual (CLASS, Pre-K; Pianta, LaParo, \& Hamre, 2008). Two well-trained senior researchers established the training. The first training session (4 hours) consisted of an introduction to the CLASS measures, clarification of the criteria for scoring, a practice scoring session using a 30-minute video recording of a preschool classroom lesson, and a discussion on scoring discrepancies. A fter the first training session, the observers worked in pairs to conduct practice scoring (2-3 hours) in preschool classrooms which were not participating in the follow-up study. In the second training session (3 hours), their inter-rater agreement was analyzed, discrepancies between scores and points of divergence were identified, and criteria were clarified once again as needed. Ratings that were within 1 point of each other were considered to reflect an acceptable degree of rating accuracy (see Pianta et al., 2008). In cases where a pair of observers showed a discrepancy of more than one point, extra scoring practice was required using recorded video material and a meeting was arranged to check the subsequent inter-rater agreement. Extra practice was needed in the case of two pairs of observers. Inter-rater reliability between the pairs of observers was determined from the actual observation data (i.e., after the full two-day training had been completed) by calculating intra-class correlation coefficients. All of the inter-rater reliabilities were high and varied between .80 and .96 on the first observation day (except .63 for Concept Development), and between .76 and .94 on the second observation day. On the second observation day, the inter-rater reliability for Concept Development was .86 . 
INSTRUCTIONAL TEACHING PRACTICES IN PRESCHOOLS

Each of the four preschool classrooms was observed on two different days, three hours at a time. The observations were conducted using 30-minute observation cycles in which a 20 -minute observation period was al ways followed by a 10-minute rating period. A total of 6 to 10 observation cycles were rated per teacher across two days in regard to the three domains (i.e., emotional support, classroom organization, instructional support) of the CLASS. The observers did not participate in the ongoing activities, but instead took notes at the back of the classroom. During the 20-minute observation period, to make it easier to perform the quantitative ratings of the CLASS, the observers took notes on teachers' practices and interactions with the children. During the 10-minute rating period, notes were not taken. The observers also added a remark on the CLASS scoring sheet if something noteworthy occurred (e.g., quarreling between children that disturbed the activities) that may have had an effect on the ratings made during the observation cycle. The notes made by observers served as a useful tool if the sound recording of the session was of poor quality or if something unusual occurred in the classroom during the observation period.

The four teachers studied here carried an M P3-recorder during their morning assembly (i.e., the times for educational activities are in the morning, before lunch and before nap time). All of the recordings were transcribed. These transcripts of the authentic classroom interactions provided the data for our descriptive case analysis. A Itogether, 10 tape recordings (i.e., 6 hours in total covering at least 6 cycles per teacher) and 92 pages of transcribed text formed the data for our qual itative anal yses in this study.

Teacher Q uestionnaire. In order to reflect teachers' educational goals and their observed teaching practices, the teachers were asked to fill in a questionnaire. The questionnaire was filled in before the observations. Teachers were asked to complete questionnaires on their demographics (e.g., basic education, years of working experience in educational settings, number of children and 
INSTRUCTIONAL TEACHING PRACTICES IN PRESCHOOLS

additional personnel in the classrooms), curricular goals, and instructional activities concerning the amount of academic activities provided. First, teachers were asked to rate the goals of the preschool curriculum on a 5-point scale (i.e., "How important do you find it to support the following skills in your classroom? 1 = not important at all, 5 = very important" $)$. Second, teachers were asked to rate 22 items pertaining to curriculum-based, instructional preschool classroom practices in literacy and mathematics on a 5-point scale (i.e., " How often do you use the following activities in your classroom? $1=$ not at all, $2=$ seldom, $3=$ weekly, $4=$ daily, $5=$ several times a day" $)$. B oth sets of questions were based on a study by Stipek and Byler (2004) and the descriptions were formulated on the basis of the Core Curriculum for Pre-school Education (2000).

\section{Data Analysis}

\section{Analysis Strategy}

The CLASS (Pianta et al., 2008) framew ork and dimensions (i.e., concept development, quality of feedback, language modeling) under the domain of instructional support were used as thematic headings in our content analysis. The strategic idea was to be attentive to how the teachers expressed their instructional practices in relation to the three dimensions attributed to the CLASS domain of instructional support and to analyze the qualities and features of the teachers' practices accordingly. The main aim was to discover what kinds of instructional practices would be found in the Finnish data and how they were being expressed. In this particular analytical approach, we followed the principles of theory-driven qualitative content analysis (see Patton, 2002). A ccording to Patton (2002), qual itative content analysis is used to reveal predominant phrases, concepts, and core meanings in text documents and is appropriate to various types of qualitative data and depths of interpretation (Graneheim \& Lundman, 2004). 
INSTRUCTIONAL TEACHING PRACTICES IN PRESCHOOLS

The analysis proceeded in three stages. Throughout these stages of the analysis, the data were repeatedly read through and each teacher's instructional practices became more and more recognizable and reconstructible in the process. At the first stage, which mainly concerned the organization of the data, the transcribed teacher-child interactions were analyzed in relation to each of the three dimensions of instructional support; in other words, expressions of concept development, quality of feedback and language modeling were determined and selected from the data. This stage was deductive and theory-driven (Patton, 2002) by nature since it relied on the existing CLASS framework. A s the types of interactions were emerging in the data, different color codings were assigned to the teachers' practices according to these three dimensions. Segments of transcripts (i.e., meaningful interactional episodes including features of instructional practices), rather than single words, were treated as units for analysis, or as Graneheim and L undman (2004) phrased it, as meaning units. I rrelevant interactions were excluded. For example, the segments where a teacher concentrated mainly on discussing a matter with other adults in the classroom were considered inappropriate for the analysis in this study. A fter finding such segments in the data of all four teachers, the segments were labeled according to very simple themes within each of the CLASS dimensions to help handling the large amount of qualitative data. For example, under the dimension of concept development, expressions of constructive interactions where a teacher used more difficult concepts were labeled as gives challenges.

A the second stage, we aimed to gather the practices that best demonstrated each teacher's typical way of working in relation to the three dimensions of instructional support. This stage of the analysis can be seen to enter the heart of qualitative content analysis, where the goal is to attempt to identify and structure core consistencies and meanings (G raneheim \& Lundman, 2004; Patton, 2002). The four teachers' data were placed side by side and one organizational theme (created at stage one) 
INSTRUCTIONAL TEACHING PRACTICES IN PRESCHOOLS

at a time was sought within their data. For example, in the case of the gategory gives challenges, it was important not only to compare how the four teachers were using language and concepts in providing challenges, but also how they were providing support and encouraging children. All of the categories were filtered out of the data in a similar way for all four teachers to ensure that the variety among teachers was determined for each of the three CLASS dimensions as effectively as possible.

At the third stage of analysis it was essential to complement the data of the observed practices with the information pertaining to the teachers' self-reported educational goals. We continued to work with the data of all four teachers side by side from where left off in the second stage. If, for example, one of the teachers was seen to be a strong example for challenging children to surpass their current knowledge during the observed teaching sessions it made sense to also check how the teachers selfrated the goal of supporting children's problem solving and thinking skills, in turn enabling us to compare and understand how they produced such practices in authentic classroom situations. A lso, if a certain way of teaching was common to all teachers, then we checked to find out whether there was a certain self-reported goal which they similarly viewed as important. Througout the analyses, the focus was on describing the variety of instructional teaching practices through complementing the observed practices with teachers' self-reported goals.

\section{Results}

\section{General Description of the Teacher Cases}

In the following subsections, the four teachers' instructional practices are described according to the aforementioned CLASS constructs, and data on teachers' self-reported goals are also provided (see Table 1). N ext, the cases are illuminated one by one, starting with the teacher who represents Profile 1. 
INSTRUCTIONAL TEACHING PRACTICES IN PRESCHOOLS

*Table 1 about here*

\section{Profile 1: Teacher A}

Concept development. Even though Teacher A spent an entire instructional period concentrating on a single topic (e.g., the letter " $K$ "), she nevertheless provided a good variety of exercises on the topic (e.g., differentiating the name of the letter from the phoneme, and having the children form the letter with their bodies). A lthough this teacher sometimes focused on drilling basic academic skills in her instruction, she also made references to previously learned skills and brought clear connections with these to attention. The instructional practices of Teacher A appeared to reflect a particularly high pedagogical awareness and flexibility. For example, she frequently introduced a task by describing its goals and clarifying its relevant concepts through examples (e.g., rhyming pairs) which enhanced the children's learning process. In addition, this teacher was able to provide the children with tasks of slightly increasing difficulty in a sensitive manner, so that their skills were challenged but without causing frustration. For instance, the teacher asked the children to summon up the musical concepts and signs for loud ("forte") and quiet ("piano"), terms which they had learned before.

Q uality of feedback. The feedback provided by Teacher A was efficient and logically altered in different educational interactions. Her feedback was often about the correctness of the answer, but she also aimed to include more feedback on the process of learning every now and then when it was appropriate. The teacher frequently and consistently provided hints and scaffolding for the performing of tasks in group situations as well as for individual children (e.g., "N ow that we have gone through these examples together, please continue on your own"). 
INSTRUCTIONAL TEACHING PRACTICES IN PRESCHOOLS

L anguage modeling. Conversations in the classroom were mainly teacher-driven, but Teacher A was constantly and intentionally inviting the children to take part in conversations (considering both social and academic issues). The children did so by answering the teacher's questions and by making comments which ranged from relatively short to more elaborate remarks. Teacher $\mathrm{A}$ used rich and age-appropriate language and usually explained concepts in terms that the children could easily understand (e.g., "listening ears" for paying attention to instructions or "the letter ' $K$ ' sounds a bit like a horse galloping"). The teacher verbally and actively modeled the ongoing activities and elaborated on the children's answers.

\section{Teacher A's prevailing instructional teaching practices in relation to her educational}

goals. Extract 1 that follows, aims to describe Teacher A's typical way of applying instructional practices in her classroom. In the extract, the teacher has just finished reading a story to the children and now she is discussing it with them. Related to this, Teacher A reported particularly reading often to the children ( $5=$ several times a day), more so than the other teachers. Even though the original question concerns the plot of the story, Teacher A was able to use the child's simple answer and build new information on it which gives the children a chance to elaborate on the topic at hand and build up their understanding. Teacher A used this type of leading question relatively often in order to generate additional information. The extract also shows how the teacher was efficiently leading the conversations nearly all of the time while modeling the ongoing activities; simultaneously, the children were provided with opportunities to participate. This can be seen as a reflection of the teacher placing a high emphasis on curricular goals in preschool $(4=$ important, and $5=$ very important), particularly concerning the development of the children's positive self-concept and learning motivation, while having placed a somew hat lower emphasis on the learning of factual 
knowledge ( 3 =quite important). Lower emphasis on factual knowledge may also indicate building knowledge together with children instead of teaching new concepts solely through rote learning.

Extract 1: Teacher A, Observation Day 2. (All extracts have been translated from Finnish to English by the authors; $\mathrm{T}=$ teacher, $\mathrm{C}=$ child $)$

T: In this story, something made 'Teppo the dog' feel especially good about himself. Why do you think Teppo felt so good down in his heart? [Teacher tapping her chest]

C: I think it was because he was praised.

$\mathrm{T}$ : He was praised! $\mathrm{Y}$ es. W hat do you think it means when someone is being praised?

C: It means that someone tells you: 'Oh, how great you are!'

$\mathrm{T}: \mathrm{Y}$ es, that's right. Has anyone ever praised you for something?

$C: Y$ eah! [ $M$ any children together]

C: $M$ y mom and dad.

$\mathrm{T}$ : $Y$ eah? How did that make you feel?

C: Nice! Good.

$\mathrm{T}$ : Did you feel it down in your heart?

C: No! [M any children exclaiming together; laughter]

$\mathrm{T}$ : Where did you feel it then? [T eacher laughs]

C: I don't know. In my mind I guess.

$\mathrm{T}$ : In your mind, yes, that's possible. But indeed, sometimes it feels good deep inside your heart when someone really praises you, I mean, says 'thank you' or tells you that you have done well.

\section{Profile 2: Teacher B}

Concept development. Teacher B asked relatively many open-ended questions (whyquestions, e.g., asking why a child had chosen a certain picture and asking the child to say more about the picture), al ong with closed questions checking on whether or not the child knew the right answer. She often made links between the things the children were learning in preschool and events in the children's lives outside the classroom. In a discussion about newspapers, for instance, the teacher asked each child how his or her parents usually read the newspaper or whether they read it to him or her as well.

Q uality of feedback. The feedback provided by this teacher was somewhat less systematic than that of Teacher A. Teacher B did use efficient practices to support the children's learning and 
INSTRUCTIONAL TEACHING PRACTICES IN PRESCHOOLS

active participation, but she did so in a less consistent manner. The teacher, for example, sometimes invited the children to give more explicit replies and to build on their answers, but at other times did not seem eager to do so. Teacher B provided children with multiple hints (such as helping them to remember the initials of children's names) and was also paying attention to how children use these hints as a tool to proceed with their tasks.

L anguage modeling. The teacher conversed with the children and asked them to give explanations and arguments for their responses. Teacher B used self-talk and verbally modeled activities during both group and individual instruction in order to aid children in understanding what the goal of each activity and the target of learning was. This provided a good support for children to productively engage in ongoing activities. This type of support, however, was not continuous and sometimes it seemed that the teacher got carried away from the relevant topic of the conversation.

\section{Teacher B's prevailing instructional teaching practices in relation to her educational}

goals. Extract 2 provides an example of Teacher B's typical way of utilizing instructional practices in her classroom. In this extract, at the beginning of lesson, the teacher is instructing children on a task that features identifying and extracting initials from words. In general, this teacher had reported placing slightly more emphasis on practicing pre-skills in literacy ( $3=$ weekly, and $4=$ daily) than in mathematics ( 2 = seldom, and $3=$ weekly). The extract shows Teacher B supporting the children's understanding of letters through familiar examples (own name) and by encouraging them. It also shows the teacher's use of rich language in answering the children's questions and providing elaborative information. These observed practices seem to reflect this teacher's high emphasis ( $4=$ important, and $5=$ very important) on the importance of the children's positive self-concept, learning motivation and problem solving skills; and a somewhat lower emphasis on the learning of factual knowledge ( 3 = quite important) as was al so the case with Teacher $\mathrm{A}$. The children were given 
relatively good opportunity to participate and express themselves in this teacher's classroom, but interactional episodes were usually not much longer than the one presented in Extract 2 and the focus of the educational interactions often shifted from constructive learning to rote learning.

Extract 2: Teacher B, Observation Day 2.

$\mathrm{T}$ : Touko, please tell us, what letter does your first name start with?

$C:$ ' $T$ '.

$T$ : With the letter ' $T$ '. How about 'J oonas'?

$C:$ ' ' '.

T: With 'J'. How about 'V eera'?

C: I don't know.

$\mathrm{T}$ : V eera's name starts with a ' $\mathrm{V}$ '. V eera, do you remember what the letter ' $\mathrm{V}$ ' looks like?

$C:$ [V eera makes a gesture showing her knowledge]

$\mathrm{T}$ : $Y$ es. Please go and write the letter ' $\mathrm{V}$ ' on the board there. J oonas, you may go and write the first letter of your name on the board, the initial. A nd Touko, you yours. 'J', good! Y es! Okay then. A nd here we have these newspapers. A nd now again, you may leaf through like so and $V$ eera will search for words starting with ' $\mathrm{V}$ ', Touko those starting with ' $\mathrm{T}$ ', and J oonas those starting with 'J'. A nd then you can start cutting them out. Okay ? Y ou cut them out and then glue them.

C: I found one here!

T: Y es, that's right, you found one! And it starts with a 'J'. Y ou know what? That one is a name as well; the one you are cutting out right now. It says 'J aana'.

C: 'Jaana'.

T: Y es. Do you remember that we have a 'J aana' here in school right now? J aana, the school helper.

\section{Profile 3: Teacher C}

Concept development. Teacher $\mathrm{C}$ was able to effectively introduce important concepts to the children in the classroom most of the time. She explained and highlighted essential concepts and encouraged the children to pay attention to these during the activities that followed. The teacher sometimes also established connections between the things that were being studied at the time and things that had been learned earlier (e.g., by saying, "As we all remember, we were recently exploring those glass jars and counting the pearls inside them, and now you can see similar jars here in your exercise books"), but the connections were rather superficial. Despite the occasional support for 
INSTRUCTIONAL TEACHING PRACTICES IN PRESCHOOLS

children's deeper thinking skills, the main emphasis was placed on the drilling of basic skills related to letters that words start with, the number of syllables in the words, and numbers.

Q uality of feedback. The teacher's way of giving feedback to the children during the observed sessions was of rather low quality. Instructional interactions during storytelling, for example, were focused on the amount of correctly remembered details and being able to recognize the characters of the story, instead of promoting thinking and making inferences concerning the story. The teacher provided general feedback (e.g., "good"|"yes "/"well done"), but the feedback was aimed at hitting upon the right answer or drilling factual knowledge. The teacher used fairly many hints to support the children's progress with various tasks and exercises (i.e., to arrive at correct answers), but the hints did not serve as a tool to enhance their deeper understanding of the learning process.

L anguage modeling. The teacher was leading the conversations with such control that the children had only few genuine opportunities to share what they thought. On a few occasions, children initiated discussion and the teacher would respond, but the conversation on these topics never lasted longer than a few minutes. The teacher repeated the children's answers quite frequently and by doing so provided a clear structure for the proceeding of the exercises and instructional conversations. However, she did not expand on the children's answers with her own comments or more complex language (i.e., to extend the children's knowledge), that would have supported the development of the children's thinking skills. Teacher $\mathrm{C}$ used a fair amount of self-talk and verbal modeling which clarified the goals of the ongoing activities and made following them and participating easy for the children; however, she did not do as good a job in supporting the children's understanding of concepts.

\section{Teacher C's prevailing instructional teaching practices in relation to her educational}

goals. Extract 3, shown next, can be considered as being a typical example of Teacher C's regular interaction with the children in her classroom. The teacher has been reading a story to the children 
and asked them beforehand to pay attention to the numbers 6 and 7 while listening. The extract shows how the teacher is predominantly drilling basic skills and paying attention to how the children are able to remember factual parts or details of the story and to correctly answer questions. This teacher had reported a high emphasis on problem solving and thinking skills (5 = very important) as Teacher B had done, but Teacher $\mathrm{C}$ additionally reported often practicing use of the pen $(5=$ several times a day) and play-writing ( $4=$ daily) with children. Counting numbers, learning basic mathematical concepts, and operating with numbers smaller than 10 were also practiced with frequent regularity (4 $=$ daily), which al so indicate the higher extent of drilling basic skills in this classroom. The extract also shows how Teacher $\mathrm{C}$ is effectively modeling the ongoing activities, but it also reveals that the modeling does not support deeper thinking skills or enhance the learning process very efficiently.

Extract 3: Teacher C, Observation Day 1.

$\mathrm{T}$ : But had 'Teppo the dog' actually seen the dragon?

C: No! [Children responding together]

$\mathrm{T}$ : No he hadn't. A nd can you tell me why?

$C$ : He was having a dream.

T: Y es, 'Teppo the dog' couldn't have really seen the dragon because he was having a dream! Now, do you remember that $I$ asked you to pay attention to the numbers 6 and 7 when we started to read the story? I would like you to tell me now what kinds of things you remember that had something to do with these numbers. Who would like to start? Kirsi?

$T$ : The dragon had seven toenails on each foot.

T: Y es. Y ou may come here and draw the nails on the dragon's foot. Do you remember something else? J aakko?

C: There were seven horns on its head.

$\mathrm{T}$ : How many horns were there actually? I think in the story it said there were only six.

\section{Profile 4: Teacher D}

Concept development. Instructional variety in this classroom consisted mainly of drilling basic skills and posing questions aimed at receiving factual or correct answers. Teacher $D$ did not show clear links between what was being discussed in the moment and other recently learned concepts; instead, she repeated the concepts again without clarifying connections. It seemed that the 
INSTRUCTIONAL TEACHING PRACTICES IN PRESCHOOLS

teacher had very clear plans for different activities (mostly rote learning) and she was guiding the children according to these plans instead of taking their initiatives into account. As a result, the development of higher order thinking skills was rarely supported in this classroom. On a positive note, the teacher connected concepts to events familiar to the children in their everyday lives. She also used a few occasions to provide explanations which facilitated the children's understanding (e.g., engaging the children in a discussion concerning the differences between two different triangles by using terms that the children could easily understand).

Q uality of feedback. The feedback provided by Teacher D mostly focused on the correctness of the children's answers instead of providing further information on what was wrong with the replies and how the children could learn from their mistakes. The feedback provided by this teacher was also mostly perfunctory and merely concerned the outcome of the different tasks (i.e., "Y es, that's right" and, "Good, and now we can move on"). The teacher was not always paying attention to children's answers and was unable to use them smoothly as a resource for further explanation.

L anguage modeling. Teacher $D$ engaged the children in conversation on a few occasions, but these lasted only a relatively short time. A n open discussion of ideas was rare and the teacher mainly asked closed questions (e.g., "W hat form is this?"|"How many corners?"|"Is that a square?") for which the children were provided only little time to answer. The discussions in this classroom often concerned behavioral and managerial tasks rather than educational or productive topics (e.g., a few children were behaving poorly and the teacher was trying to calm them down). This teacher verbally modeled the activities less clearly than the other teachers (e.g., she did not verbally describe the activities that are ongoing or upcoming). This made it difficult for the children to understand what was expected of them in the various activities and how to participate in discussions. 


\section{Teacher D's prevailing instructional teaching practices in relation to her educational}

goals. In Extract 4 that follows, Teacher D's most typical way of providing instructional support is captured. The teacher is telling an educational story about dinosaurs to the children and has adopted the role of an old wise owl as narrator. The extract shows that the teacher is dominating the learning situation and directs the discussion of the topics with an inflexible approach. Eliciting responsive feedback or engaging the children in conversation occurs inconsistently and the teacher often skips good learning opportunities by ignoring the children's initiatory comments and remarks. Teacher D's self-reports provide support to the teacher's use of these practices in that despite having reported placing an equal emphasis on motivational goals, positive self-concept and academic pre-skills ( $4=$ important), she also reported that she places clearly less emphasis ( $1=$ not important at all) on the goals of developing problem solving and thinking skills. In addition, this teacher reported practicing most academic skills on a regular basis ( $3=$ weekly), but not practicing listening comprehension at all ( 1 = not at all). Consequently, good conversational learning opportunities are often being missed in this classroom as the teacher sticks to the structure of the lesson planned beforehand as can be seen in the following lesson extract.

Extract 4: Teacher D, Observation Day 2.

$\mathrm{T}$ : Then the dinosaur came, stepping towards my tree. [T eacher makes the sounds of heavy steps]

C: Did it have a long neck?

$\mathrm{T}$ : I took a peek into my nest, and yes it had a long neck and absolutely huge feet!

$C:$ W ell, it was a herbivore then.

$\mathrm{T}$ : Does the length of the neck mean that the dinosaur is a herbivore?

$C: Y$ es, and the name of that kind of dinosaur is [... ]. [Teacher interrupts the child]

T: Okay.

C: It eats vegetables. [Teacher interrupts the child]

$\mathrm{T}$ : Y es. B ut you know what happened next? W hen I took a peek from my nest [... ]. [Teacher continues telling the story]

Differences and Similarities B etween T eachers' Instructional Practices and Self-Reported

\section{E ducational G oals}


INSTRUCTIONAL TEACHING PRACTICES IN PRESCHOOLS

The prevailing practices of each teacher are presented in a short format in Table 2. Teacher A differed from the other teachers in having applied instructional practices of a higher quality in all three domains of instructional support. Teacher A aimed at constructing knowledge together with the children by providing feedback during interactional discussions, for example, by asking a question and building another question on the child's answer. In this regard, Teachers A and B shared rather similar practices, but Teacher B produced them in a somewhat less consistent manner. Conversations were common between Teacher A and the children, but the teacher was always leading the conversations. Teacher A's questionnaire ratings on the frequency of academic activities in her preschool classroom provided additional information about her instructional practices that was useful for comparisons with the other teachers. For example, Teacher A reported practicing counting numbers and operating with numbers greater than 10 more frequently than Teachers $B, C$ and $D$ had indicated. This could be seen as an indicator of Teacher A's higher quality of concept development as she was giving the children more challenges that enhanced and challenged their thinking and learning in a unique way. Teacher A reported practicing initial phoneme recognition and operating with syllables on a weekly basis in her classroom. This was also clearly observed in Teacher A's classroom practices as she often focused the children's attention on letter-sound correspondence and thus supported children's conceptualizing of letters and the use of letters in words more thoroughly in comparison to the other teachers. Overall, the reports reflect the finding that the provision of support for children's deeper conceptual understanding was observed most frequently in the classroom of Teacher $\mathrm{A}$.

Table 2 about here 
INSTRUCTIONAL TEACHING PRACTICES IN PRESCHOOLS

Despite the similarities between Teachers B and C in the CLASS ratings for the domain of instructional support, these two teachers differed quite clearly in their observed teaching practices. Firstly, Teacher B was taking children's initiations, ideas and comments into consideration with greater sensitivity, whereas Teacher $\mathrm{C}$ was doing most of the talking herself and allowing children only short turns to answer. Teacher B invited children to share their ideas through talk more frequently and was able to simultaneously monitor their understanding in this way, whereas Teacher C invested a greater amount of time in exercises of basic skills conducted in a teacher-directed fashion. Secondly, during educational activities, Teacher B was building more effectively on the children's previous knowledge and providing more additional information concerning the theme at hand in comparison to Teacher C. Thus, teacher B's individual strength in teaching was her highquality feedback, while Teacher C's individual strength was performing effectively in modeling the activities through language. B oth of these teachers' self-ratings of their instructional practices also proved to be associated to their observed classroom practices. Teacher $\mathrm{C}$ reported having children practice the use of the pen and basic mathematical concepts with more frequency than Teacher $B$, while Teacher B emphasized the learning of factual skills less than Teacher C. Further, Teachers A and $\mathrm{C}$ both reported practicing certain basic skills (e.g., counting numbers, using basic mathematical concepts) on a regular basis, but Teacher $\mathrm{A}$ was better able to utilize these instances as challenges made interesting for the children, whereas Teacher $\mathrm{C}$ introduced them for less inspiring rote learning. Together, these findings can be seen as a further reflection of Teacher C's observed practice of drilling basic skills and emphasizing correct answers in favor of developing the children's process of learning.

Teacher $D$ stood out from the other teachers by deploying instructional practices of considerably lower quality in all dimensions of instructional support. The absence of an organized 
INSTRUCTIONAL TEACHING PRACTICES IN PRESCHOOLS

learning environment combined with instructional practices lacking in conscientious awareness may have made it more challenging for this teacher to conduct effective instructional activities while also being sensitive to the children's needs and their efforts to actively participate. When Teacher $D$ was asked to evaluate the importance of different curricular goals, her rating indicated less emphasis on the importance of factual knowledge, language and conceptual skills compared to the other teachers. A related revelation was that when instructional practices were self-rated, Teacher $D$ reported not practicing listening comprehension and letter-sound correspondence at all in her classroom. These differences underlined the ineffectiveness of Teacher D's instructional practices, particularly through the emphasis on drilling basic skills rather than supporting deeper thinking. Teacher $D$ also placed less curricular emphasis on the development of thinking and reasoning skills compared to the other teachers. This may be linked to only a low amount of support having been given to the children to participate in conversations and for constructing knowledge together with the teacher through effective feedback.

Two related issues should be considered concerning Teacher D. First, what was common for Teachers A, B and C was that they all shared a relatively long working history in educational settings (more than 15 years), whereas Teacher D's history was clearly shorter (1 to 5 years). A teacher's awareness of children's academic skills and progress is likely to develop not only with teaching experience but also with knowledge of the individual children in the classroom and additional inservice training (E arly et al., 2007; LaParo et al., 2009). This is possibly the case in light of the fact that Teacher $D$, who had the least teaching experience of the four teachers observed, often failed to respond to children's initiatives and academic needs. Second, Pianta et al. (2002) have proposed that there is a connection between higher quality instructional practices and children being positively engaged in on-task behavior in the classroom. This finding is noteworthy for the present study given 
INSTRUCTIONAL TEACHING PRACTICES IN PRESCHOOLS

that Teacher $D$, who had only seven children in her preschool classroom, had the most problems with children exhibiting more off-task and disruptive behavior than is usual. It seems that a teacher's constructive and conversational stance toward children, as observed in Teacher A's classroom, helps children to fully engage in ongoing activities.

\section{Discussion}

The present study aimed to examine the diversity of teaching practices and to illuminate the qualitative variety of instructional teaching practices among preschool teachers by adopting a qual itative case study approach. Further, teachers' self-rated educational goals were explored to complement the understanding of the multifaceted nature of preschool teachers' instructional teaching practices. Four teacher cases were selected and their instructional practices examined. Our results showed how the instructional practices provided by teachers created different learning atmospheres in the four classrooms studied. The results indicated that Teachers A and D clearly differed from Teachers B and C in their classroom practices. W hile Teacher A provided the highest quality instructional practices and Teacher $D$ the lowest, both teachers were observed to be deploying a unique combination of practices. The results also showed that teachers' descriptions of their educational goals were congruent with their observed practices in authentic classroom situations, indicating that teachers actually practice what they report. In general, the results seemed to reflect the real-life instructional practices in Finnish preschool classrooms where teachers are relatively free to produce teaching practices within the general curricular guidelines; the goals are common, but the daily work is determined by each teacher's personal way of teaching, thus yielding a variety of instructional practices (c.f., Core Curriculum for Pre-school Education, 2000; Office for Standards in Education, 2003). It is al so notew orthy that structural features such as materials and the physical 
INSTRUCTIONAL TEACHING PRACTICES IN PRESCHOOLS

environment are highly similar in preschool classrooms throughout the country; hence, other factors must explain the differences in the variety of classroom quality. The main results of this study and their connections to previous literature are discussed next in terms of teachers' practices within the three CLASS dimensions (i.e., concept development, quality of feedback and language modeling) under the domain of instructional support.

\section{Concept Development}

Several high-quality instructional practices were noted in the classrooms observed for this study, but not all teachers utilized these in a consistent manner. Teacher $A$, and to a slightly lesser extent Teacher B, produced practices that supported children's skills in concept development and facilitated gaining deeper understanding. These practices, for instance, consisted of linking concepts to familiar contexts and utilizing children's prior knowledge as a basis for learning. In addition, Teachers $A$ and $B$ had a more active dialogue with children than Teachers $C$ and $D$; similar practices have also been associated with effective teaching in earlier studies (W ebb et al., 2008; W harton-M cD onald et al., 1998). Furthermore, Teacher A produced challenging tasks for children which enabled them to efficiently construct knowledge. Similar findings on the importance of providing moderate amounts of challenges for children and the resulting higher quality of concept development within their academic progression have also been found in previous studies (e.g., B ohn et al., 2004; Curby, LoC asale-Crouch, et al., 2009).

\section{Q uality of Feedback}

Teacher $C$ self-reported placing a lot of emphasis on many important skill areas in preschool and she succeeded in creating many learning opportunities for the children in her classroom. However, other than merely answering their questions, she very rarely engaged the children in discussions. A lack of productive and useful feedback was therefore apparent when compared to Teachers A and B. 
INSTRUCTIONAL TEACHING PRACTICES IN PRESCHOOLS

These findings are in line with research suggesting that a lack of effective feedback makes it unclear whether interactions have provided understanding (B urnett, 2002; NICHD/ECCRN, 2002; Perry et al., 2007). The results of previous studies also suggest that teachers' use of more reciprocal conversations and feedback provide more support to children's thinking skills (e.g., Curby, Rimm-K aufman, et al., 2009; W ebb et al., 2006). These types of practices were apparent in the classroom of Teacher A and sometimes in that of Teacher B, and these were al so the classrooms where the practices supporting children's concept development were of a higher quality. Thus, the results of this study seem to reflect similar connections.

\section{L anguage M odeling}

Common to all four teachers, including Teachers $A$ and $B$, was that they were not as active as they could have been in inviting children to participate in educational activities and particularly in discussions, which may have contributed to the fact that the observed practices of language modeling were not representing the highest possible quality even in the better classrooms. Although Teachers A and B had created a relatively open and respectful environment for discussion in the preschool classrooms, even these teachers could have provided the children with yet more opportunities for sharing their ideas. A similar finding has been reported in a previous study comparing preschool educational practices in England, Denmark and Finland (Office for Standards in Education, 2003); namely that even though Finnish teachers had the smallest groups of children in the classrooms of the countries compared, the amount of extended interactions and conversations between teachers and children was relatively slight. Previous research has also suggested that the provision of high quality language stimulation and supporting children to articulate their thought processes enhances the children's cognitive development (H owes et al., 2008; M ashburn et al., 2008); however, the utilization of these types of instructional discussions is rather inconsistent (NICHD/ECCRN, 2002). In line with 
INSTRUCTIONAL TEACHING PRACTICES IN PRESCHOOLS

the results of these other studies, the descriptive results of our present study similarly suggest that more attention should be given to how Finnish preschool teachers support children's participation in discussions, thereby constructing knowledge together with peers and teachers. There exists a contradiction when a teacher acts as sole director of all classroom activities, conversations and learning, while the binding curricular guidelines and previous research (Core Curriculum for Preschool Education, 2000; Hännikäinen \& Rasku-Puttonen, 2010) clearly emphasize that selfdetermined and active participation by the children in the learning processes is also of high importance.

In our research, we further examined whether teachers' observed practices and their reports of their educational goals reflected a similar direction (e.g., high self-reported emphasis on problem solving and thinking skills - in line with - frequently observed high-quality conversations about concepts). The results of this study, showed that teachers' practices and self-reported goals were congruent. Such congruency has also been reported in previous studies. For example, teachers who were observed as emphasizing the learning of basic skills in their classrooms had al so rated the acquisition of basic skills as an important goal; teachers who were observed to develop more constructive practices, in turn, reported placing less emphasis on the area of basic skills (Lerkkanen et al., in press; Stipek \& Byler, 1997; 2004).

\section{Limitations}

There are al so some limitations to this study that need to be considered. To begin with, while exploring teaching practices through individual case studies yielding rich descriptions of teachers' current practices, our study does not provide information on the effects of these practices on child outcomes or on how the children experience these different classroom practices. Furthermore, these results were derived from a small sample of Finnish preschool classrooms where the data were gathered within a relatively short time frame, meaning the results are not widely generalizable. In 
INSTRUCTIONAL TEACHING PRACTICES IN PRESCHOOLS

future research, it would be important to more carefully explore how instructional practices affect children's learning and development by utilizing a longitudinal research approach covering a long time span. This type of approach would make it possible to determine the effects of teachers' observed professional development over time in regard to their instructional practices. What our current results do provide, however, is a rich description of how differently teachers may work even in a highly homogenous educational system like that in Finland. While the focus of the current study was on the instructional practices produced by the four selected teachers, it is also worth noting that these practices represent only a small part of their actual work with children and that the differences between the teachers in the domain of instructional support could also be explained through their practices in the other CLASS domains of emotional support and organizational support. These other two domains could not be dealt with in detail within the boundaries of this study as our focus was decidedly on the CLASS domain of instructional support. It should also be noted in the present study, as is al so the case in qualitative research in general, no broad generalizability of the results was sought. It has been suggested that instead of discussing the generalizability of qualitative studies, their transferability and trustworthiness should be addressed (Lincoln \& Guba, 1985; Patton, 2002). By this is meant that instead of largely drawing conclusions and generalizing findings from data based on only a few individuals, the value of such cases lies in presenting features (as in the case of the present study on teachers' practices) that readers can apply to their prevailing contexts and experiences. In order to make this possible, it is necessary to provide a detailed description of the context, method and analysis of the study, giving readers access to the contents of the study (Lincoln \& Guba, 1985). In addition, findings in the present study that are in line with earlier studies further support the trustworthiness of the current study (Guba \& Lincoln, 1989). The value of case studies can be seen to be in naturalistic generalizations: The power of a case study lies within constructing knowledge 
INSTRUCTIONAL TEACHING PRACTICES IN PRESCHOOLS

together with the readers, by providing information in a form in which they usually experience it (i.e., rich description of instructional practices) (Denzin \& Lincoln, 2000; Lincoln \& Guba, 1985).

\section{Conclusions and Implications}

The present study provided interesting results on the differences between preschool teachers' instructional practices assessed through direct observation. On the basis of the results from a previous, related profiling study by Salminen et al. (in press), it was possible to give a rich description of the differences between the teachers in the four teacher profiles. Furthermore, our current study has yielded a deeper knowledge of how these teachers actually produced their individually differing instructional practices. In future studies, it would be useful to also explore the data of teachers who have the same profile side by side in order to reveal the micro-patterns of the instructional practices that combine these teachers into the same profiles.

The case study approach applied to our present research can be seen to increase the value of previous CLASS studies by describing the processes of teaching in actual classroom situations and providing more precise information about how different teaching practices are used in different classrooms under the same legislation and guidelines (Core Curriculum for Pre-school Education, 2000). A $n$ important purpose of this study was to deepen the understanding and knowledge of the diversity of instructional teaching practices and by thereby contributing to the discussions on the quality of preschool classrooms. A ccordingly, our case study provides concrete, real-life examples of both good and less effective teaching practices and thereby demonstrates which instructional practices teachers should consider in striving to improve and enhance their quality of teaching and subsequently the development of the children in their classrooms. The present findings al so have potential implications for teacher training and practice for the same reasons: It may be particularly 
INSTRUCTIONAL TEACHING PRACTICES IN PRESCHOOLS

important for teachers to monitor various teaching practices, as this can make them more aware of their own work thus facilitating their own professional development.

Finnish children start formal education at a later age than children in some other countries. At the same time, international comparisons (OECD/PISA ; Programme for International Student A ssessment; OECD , 2007, 2009) have provided evidence of equally good results in mathematics, science, literacy and problem solving among 15 -year-olds. A $n$ interesting question is whether the homogenous and high-quality preschool education in Finland may play a role in this success (Ojala \& Talts, 2007). Finnish children have the opportunity to enjoy play and playfulness in educational settings even until the age of seven years, which may stimulate academic interest and motivation toward learning. Therefore, we might conclude that beginning formal schooling not too early in childhood can be beneficial to children's motivation, as seen in Finland. Based on the results of our study, we are nevertheless cautious to give any advice on how to develop early education in other countries because of the different societal and educational systems. N onetheless, the results of our study can be utilized both in the development of educational policies and the development of teachers' educational practices through teacher training and supplementary education in Finland, and possibly also in other countries. 


\section{References}

Birch, S. H., \& Ladd, G. W . (1997). The teacher-child relationship and children's early school adjustment. J ournal of School Psychology, 35, 61-79.

Birch, S. H., \& Ladd, G. W . (1998). Children's interpersonal behaviors and the teacher-child relationship. D evelopmental Psychology, 34, 934-946.

B ohn, C. M ., Roehrig, A. D., \& Pressley, M . (2004). The first days of school in the classrooms of two more effective and four less effective primary-grades teachers. The Elementary School J ournal, $104,269-287$.

B rophy, J. (1991). Teaching. Educational practices series 1. International A cademy of Education and International Bureau of Education.

B urnett, P. C. (2002). Teacher praise and feedback and students' perceptions of the classroom environment. Educational Psychology, 22, 5-16.

Connor, C., M orrison, F., \& Slominski, L. (2006). Preschool instruction and children's emergent literacy growth. J ournal of Educational Psychology, 98, 665-689.

Core Curriculum for Preschool Education (2000). [E siopetuksen opetussuunnitelman perusteet 2000]. Helsinki: National B oard of Education.

Cunningham, D. D. (2008). Literacy environment quality in preschool and children's attitudes toward reading and writing. Literacy Teaching and Learning, 12, 19-36.

Curby, T.W., LoCasale-Crouch, J., Konold, T. R., Pianta, R. C., Howes, C., B urchinal, M.,... B arbarin, 0. (2009). The relations of observed pre-k classroom quality profiles to children's achievement and social competence. Early Education and D evelopment, 20, 346-372. 
INSTRUCTIONAL TEACHING PRACTICES IN PRESCHOOLS

Curby, T.W, Rimm-K aufman, S. E., \& Ponitz, C. C. (2009). Teacher-child interactions and children's achievement trajectories across kindergarten and first grade. J ournal of Educational Psychology, $101,912-925$.

Davis, E. A ., \& M iyake, N. (2004). Explorations of scaffolding in complex classroom systems. J ournal of Child Psychology (Vol 23, pp.43-77). Hillsdale, NJ: Earlbaum.

Denzin, N. K., \& Lincoln, Y. S. (2000). Handbook of qualitative research (2nd ed.). Thousand Oaks, CA: Sage.

Early, D., M axwell, K. L., Burchinal, M ., Bender, R. H., Henry, G. T., Iriondo-Perez, J ,... Zill., N. (2007). Teachers' education, classroom quality, and young children's academic skills: results from seven studies of preschool programs. Child D evelopment, 78, 558-580.

Eccles, J. S., \& Roeser, R. W. 1999. School and community influences on human development. In M.H. Boorstein \& M. E. Lamb (Eds.), D evelopmental psychology: An advanced textbook (4th ed.). (pp. 503-554). Hillsdale, NJ: Erlbaum.

Graneheim, U. H., \& Lundman, B. (2004). Qual itative content analysis in nursing research: concepts, procedures and measures to achieve trustworthiness. Nurse E ducation Today, 24, 105-112.

Guba, E. G., \& Lincoln, Y . S. (1989). F ourth generation evaluation. Newbury Park, CA : Sage.

Hamre, B. K., \& Pianta, R. C. (2005). Can instructional and emotional support in the first-grade classroom make a difference for children at risk of school failure? Child D evelopment, 76, 949967.

Hamre, B. K., Pianta, R. C., M ashburn, A . J., \& Downer, J. T. (2007). B uilding a science of classrooms: Application of the CLASS framework in over 4,000 U.S. early childhood and elementary classrooms. (Retrieved from http://www.fcdus.org/resources/resources_show.htm?doc_id=507559) 
INSTRUCTIONAL TEACHING PRACTICES IN PRESCHOOLS

H offert, S. L., \& Sandberg, J. F. (2001). How A merican children spend their time. J ournal of Marriage and F amily, 63, 295-308.

Howes, C., Burchinal, M., Pianta, R., Bryant, D., Early, D., Clifford, R., \& Barbarin, O. (2008). Ready to learn? Children's pre-academic achievement in pre-kindergarten programs. Early Childhood Research Quarterly, 23, 27-50.

Hännikäinen, M ., de Jong, M ., \& Rubinstein Reich, L. 1997. O ur heads are the same size! A study of quality of the child's life in Nordic day care centres. M almö. School of Education. Educational information and debate 107.

Hännikäinen, M .. \& Rasku-Puttonen, H . (2010). Promoting children's participation: The role of teachers in preschool and primary school learning sessions. Early Years: An International J ournal of Research and Development, 30, 147-160.

J ustice, L. M ., M ashburn, A . J., Hamre, B. K ., \& Pianta, R. C. (2008). Quality of language and literacy instruction in preschool classrooms serving at-risk pupils. Early Childhood Research Quarterly, 23, 51-68.

K orkeamäki, R.-L., \& Goman, A . (2002). Learning to read and write in different preschool settings. [Lukemaan ja kirjoittamaan oppiminen erilaisissa esiopetuksen ympäristöissä]. Kasvatus: Suomen K asvatustieteellinen aikakauskirja, 33, 275-287.

LaParo, K. M ., H amre, B. K., LoCasale-Crouch, J., Pianta, R. C., Bryant, D., Early, D.,... Burchinal, M. (2009). Quality in kindergarten classrooms: observational evidence for the need to increase children's learning opportunities in early education classrooms. Early E ducation and D evelopment, 20, 657-692.

LaParo, K. M., Pianta, R. C., \& Stuhlman, M . (2004). The classroom assessment scoring system: Findings from the prekindergarten year. The Elementary School J ournal, 104, 409-426. 
INSTRUCTIONAL TEACHING PRACTICES IN PRESCHOOLS

LaParo, K. M ., Rimm-K aufman, S. E., \& Pianta, R. C. (2006). Kindergarten to 1st grade: Classroom characteristics and the stability and change of children's classroom experiences. J ournal of Research in Childhood Education, 21, 189-202.

Lerkkanen, M .-K ., Kikas, E., Pakarinen, E., Trossman, K ., Poikkeus, A .-M ., Rasku-Puttonen, H., Siekkinen, M ., \& Nurmi, J.-E. (in press). A validation of the early childhood classroom observation measure in Finnish and Estonian kindergartens. Early Education and Development.

Lerkkanen, M .-K ., Niemi, P., Poikkeus, A .-M ., Poskiparta, E., Siekkinen, M ., \& N urmi, J .-E. (2006). The F irst Steps Study (Alkuportaat). U npublished data. U niversity of J yväskylä. Finland.

Lincoln, Y. S., \& Guba. E. G. (1985). Naturalistic inquiry. Newbury Park, CA : Sage.

LoCasale-Crouch, J., K onold, T., Pianta, R., Howes, C., Burchinal, M ., B ryant, D., et al. (2007).

Observed classroom quality profiles in state-funded pre-kindergarten programs and associations with teacher, program, and classroom characteristics. Early Childhood Research Q uarterly, 22, 3-17.

M ashburn, A. J., Pianta, R. C., Hamre, B. K., Downer, J. T., Barbarin, O. A ., B ryant, D.,... H owes, C. (2008). M easures of classroom quality in prekindergarten and children's development of academic, language, and social skills. Child D evelopment, 79, 732-749.

M erriam, S. B. (1998). Q ualitative research and case study applications in education. San Francisco: J ossey-B ass.

NICHD, Early Child Care Research N etwork. (2002). The relation of global first-grade classroom environment to structural classroom features and teacher and student behaviors. The Elementary School J ournal, 102, 367-387.

OECD (2007). PISA country profiles. (Retrieved from http://pisacountry.acer .edu.au) OECD (2009). PISA 2009. Preliminary results in F inland. M inistry of Education. 
INSTRUCTIONAL TEACHING PRACTICES IN PRESCHOOLS

(Retriewed from

http://www.minedu.fi/export/sites/default/O P M /J ulkaisut/2010/liitteet/okm21.pdf? lang=fi)

Office for Standards in Education (Ofsted). (2003). The education of six year olds in England,

Denmark and Finland. An international comparative study. (Retrieved from

http://www.ofsted.gov.uk/0 fsted-home/P ublications-and-research/B rowse-all-by/E ducation/K ey-

stages-and-transition/Key-Stage-1/The-education-of-six-year-olds-in-E ngland-D enmark-and-

F inland/\% 28language\% 29/eng-GB)

Pajares, M . F. (1992). Teachers' beliefs and educational research: cleaning up a messy construct.

Review on Educational Research, 62(3), 307-332.

Pakarinen, E., Lerkkanen, M .-K ., Poikkeus, A .-M ., K iuru, N., Siekkinen, M ., Rasku-Puttonen, H., \&

Nurmi, J.-E. (2010). A validation of the Classroom A ssessment Scoring System in Finnish

kindergartens. Early Education and D evelopment, 21, 95-124.

Pakarinen, E., Kiuru, N., Lerkkanen, M .-K ., Poikkeus, A .-M ., Siekkinen, M ., \& N urmi, J.-E. (2010).

Classroom organization and teacher stress predict learning motivation in kindergarten children. European J ournal of Psychology of E ducation, 25, 281-300.

Patton, M. Q. (2002). Qualitative research \& evaluation methods (3rd ed.). Thousand Oaks, CA : Sage.

Peisner-Feinberg, E., B urchinal, M. R., Clifford, R. M ., Culkin, M. L., Howes, C., Kagan, S. L., \&

Y azejian, N. (2001). The relation of preschool child-care quality to children's cognitive and social developmental trajectories through second grade. Child D evelopment, 72, 1534-1553.

Perry, K . E., Donohue, K . M ., \& W einstein, R. S. (2007). Teaching practices and the promotion of achievement and adjustment in first grade. J ournal of School P sychology, 45, 269-292. 
INSTRUCTIONAL TEACHING PRACTICES IN PRESCHOOLS

Pianta, R. C., \& Hadden, D. S. (2008). What we know about the quality of early education settings: Implications for research on teacher preparation and professional development. The State Education Standard (J une), 20-27.

Pianta, R. C., \& Hamre, B. K. (2009). Conceptualization, measurement, and improvement of classroom processes: standardized observation can leverage capacity. E ducational Researcher, 38, 109-119.

Pianta, R. C., LaParo, K. M ., \& Hamre, B. K. (2008). The classroom assessment scoring system. Manual, pre-K. Baltimore, M D: Paul H. Brookes Publishing Company.

Pianta, R. C., LaParo, K. M., Payne, C., Cox, M. J., \& Bradley, R. (2002). The relation of kindergarten classroom environment to teacher, family, and school characteristics and child outcomes. The Elementary School J ournal, 102, 225-238.

Pressley, M ., Roehrig, A ., Raphael, L., Dolezal, S., B ohn, C., M ohan, L.,... Hogan, K. (2003). Teaching processes in elementary and secondary education. In W. Reynolds \& G. Miller (Eds.), Handbook of Psychology: V olume 7, Educational Psychology (pp. 153-176). Hoboken, NJ : J ohn Wiley $\&$ Sons, Inc.

Pressley, M ., Rankin, J., \& Y okoi, L. (1996). A survey of instructional practices of primary teachers nominated as effective in promoting literacy. The Elementary School J ournal, 96, 363-384.

Rautanen, R. (2007). Lasten koulunkäynti [School attendance]. In Suomalainen lapsi 2007 [The Finnish Child 2007]. (pp. 187-205). Helsinki: Statistics Finland.

Salminen, J., Lerkkanen, M .-K ., Poikkeus, A .-M ., Siekkinen, M ., Pakarinen, E., Hännikäinen, M ., Poikonen, P.-L., \& Rasku-Puttonen, H. (in press). Observed classroom quality profiles of kindergarten classrooms in Finland. Early Education and Development. 
INSTRUCTIONAL TEACHING PRACTICES IN PRESCHOOLS

Stipek, D., \& B yler, P. (1997). Early childhood education teachers: do they practice what they preach? Early Childhood Research Quarterly, 12, 305-325.

Stipek, D., \& Byler, P. (2004). The early childhood classroom observation measure. Early Childhood Research Q uarterly, 19, 375-397.

Sylva, K., Taggart,B ., Siraj-Blatchford, I., Totsika, V., Ereky-Stevens, K., Gilden, R., \& B ell, D. (2007). Curricular quality and day-to-day learning activities in pre-school. International J ournal of Early Years Education, 15, 49-65.

Vygotsky, L. S. (1991). Genesis of higher mental functions. In P. Light, S.Sheldon, \& M. W oodhead (eds.), Learning to think (pp. 32-41). Florence, KY : Taylor \& Frances/ Routledge.

W ebb, N. M ., Franke, M . L., Ing, M ., Chan, A ., De, T., Freund, D., et al. (2008). The role of teacher instructional practices in student collaboration. Contemporary Educational Psychology, 33, 360381.

W ebb, N. M ., Nemer, K. M ., \& Ing, M . (2006). Small-group reflections: parallels between teacher discourse and student behavior in peer-directed groups. The J ournal of the Learning Sciences, 15, 63-119.

W harton-M cD onald, R., Pressley. M ., \& Hampston, J. M . (1998). Literacy instruction in nine firstgrade classrooms: teacher characteristics and student achievement. The Elementary School J ournal, 99, 101-128.

W hitehurst, G.J . (2002). Scientifically based research on teacher quality: research on teacher preparation and professional development. Presented to White H ouse Conference on Preparing Tomorrow's Teachers, M arch 5, 2002. (Retrieved from http://www.ed.gov/admins/tchrqual//earn/prepairingteachersconference/ whitehurst.html) 


\section{INSTRUCTIONAL TEACHING PRACTICES IN PRESCHOOLS}

Williams, W. M ., Blythe, T., \&, W hite, N. (2002). Practical intelligence for school: developing metacognitive sources of achievement in adolescence. D evelopmental Review, 22, 162-210.

Y in, R. K. (2003). Case study research: design and methods (3rd ed.). Thousand Oaks, CA: Sage. 
INSTRUCTIONAL TEACHING PRACTICES IN PRESCHOOLS

Table 1 Teachers' Self-R eported Curricular Goals and Instructional A ctivities

\begin{tabular}{|c|c|c|c|c|}
\hline \multirow{2}{*}{\multicolumn{5}{|c|}{ Curricular Goals }} \\
\hline & & & & \\
\hline Interactional and group skills & & 5 & 5 & 5 \\
\hline Play, creativity & - & 5 & 4 & 3 \\
\hline Positive self-concept & 5 & 5 & 5 & 4 \\
\hline W orking habits, independence & 4 & 4 & 4 & 4 \\
\hline Learning motivation & 4 & 5 & 5 & 4 \\
\hline Factual knowledge & 3 & 3 & 3 & 2 \\
\hline L anguage and conceptual skills & 4 & 4 & 5 & 3 \\
\hline Literacy, phonological awareness & 4 & 4 & 4 & 4 \\
\hline M ath skills & 4 & 4 & 4 & 4 \\
\hline Problem solving, thinking & 4 & 5 & 5 & 1 \\
\hline Motor skills & 4 & 4 & 5 & 4 \\
\hline Fine motor skills & 4 & 4 & 3 & 4 \\
\hline Safety skills & 4 & 4 & 5 & 1 \\
\hline \multicolumn{5}{|l|}{ Instructional Activities } \\
\hline Reading skills: W atching books & 4 & 4 & 3 & 4 \\
\hline Reading skills: Teacher reads to children & 5 & 4 & 4 & 4 \\
\hline Reading skills: L istening comprehension & 3 & 3 & 3 & 1 \\
\hline Reading skills: Rhyming & 3 & 4 & 3 & 2 \\
\hline Reading skills: Initial phoneme recognition & 4 & 3 & 3 & 3 \\
\hline Reading skills: Spelling games & 4 & 3 & 3 & 2 \\
\hline Reading skills: Recognizing and naming letters & 3 & 3 & 3 & 3 \\
\hline Reading skills: L etter-sound correspondence & 3 & 3 & 3 & 1 \\
\hline Reading skills: Recognizing words & 3 & 2 & 3 & 2 \\
\hline Reading skills: Reading words or text & 3 & 2 & 2 & 2 \\
\hline W riting skills: Use of pen & 3 & 4 & 5 & 4 \\
\hline W riting skills: W riting letters & 3 & 4 & 3 & 3 \\
\hline W riting skills: Play writing & 2 & 2 & 4 & 2 \\
\hline W riting skills: Writing words by copying & 3 & 4 & 2 & 2 \\
\hline W riting skills: W riting words or short messages & 2 & 2 & 2 & 2 \\
\hline M athematical skills: Numbers below 10 & 3 & 3 & 4 & 2 \\
\hline M athematical skills: Numbers above 10 & 4 & 2 & 3 & 2 \\
\hline M athematical skills: N umber sequences & 3 & 2 & 2 & 2 \\
\hline M athematical skills: Recognizing numbers & 3 & 3 & 2 & 3 \\
\hline M athematical skills: Counting numbers & 4 & 3 & 4 & 4 \\
\hline M athematical skills: A ddition and subtraction & 3 & 2 & 2 & 3 \\
\hline M athematical skills: M athematical basic concepts & 3 & 2 & 4 & 3 \\
\hline
\end{tabular}

Note: Curricular Goals: How important do you find it to support the following skills in your classroom? 1 = not important at all, 5 = very important; Instructional A ctivities: How often do you use the following activities in your classroom? $1=$ not at all, 2 = seldom, $3=$ weekly, 4 = daily, 5 = several times a day 
Table 2 General Description of Teachers' Prevailing Practices according to CLASS Dimensions and Their Self-Reported Goals

\begin{tabular}{|c|c|c|c|}
\hline & \multicolumn{3}{|c|}{ Domain of Instructional Support } \\
\hline & $\begin{array}{c}\text { Dimension of } \\
\text { Concept D evelopment }\end{array}$ & $\begin{array}{c}\text { Dimension of } \\
\text { Quality of F eedback }\end{array}$ & $\begin{array}{c}\text { Dimension of } \\
\text { Language M odeling }\end{array}$ \\
\hline Teacher A & $\begin{array}{l}\text { Teacher was clarifying and } \\
\text { elaborating concepts at hand and } \\
\text { using children's prior knowledge as } \\
\text { a basis for learning. Providing } \\
\text { challenges and hence tools for } \\
\text { deeper conceptual understanding. }\end{array}$ & $\begin{array}{l}\text { Teacher provided feedback that told } \\
\text { the child whether he/she was right or } \\
\text { wrong while also providing } \\
\text { scaffolding and hints on the process } \\
\text { of learning for individual children } \\
\text { and the whole group when needed. }\end{array}$ & $\begin{array}{l}\text { Frequent teacher-driven } \\
\text { conversations, but children were } \\
\text { provided with chances to } \\
\text { participate. Teacher spoke on a } \\
\text { level which was appropriate and } \\
\text { understandable to children. }\end{array}$ \\
\hline Teacher B & $\begin{array}{l}\text { Teacher was using both open and } \\
\text { closed questions as well as } \\
\text { references to children's own lives } \\
\text { to support deeper learning and } \\
\text { knowledge. A im of teaching shifted } \\
\text { more frequently to rote learning } \\
\text { than in Teacher A's classroom. }\end{array}$ & $\begin{array}{l}\text { Teacher was using hints to support } \\
\text { children's progress in tasks and } \\
\text { providing feedback that built on their } \\
\text { answers; however, this did not } \\
\text { happen in a very consistent manner. }\end{array}$ & $\begin{array}{l}\text { Frequent conversations with } \\
\text { children, but which sometimes } \\
\text { shifted to less productive social } \\
\text { talk. Teacher asked the children for } \\
\text { explanations and argumentations. }\end{array}$ \\
\hline Teacher $\mathrm{C}$ & $\begin{array}{l}\text { Important concepts were carefully } \\
\text { introduced and explained by this } \\
\text { teacher. Connections to previously } \\
\text { learned concepts were somewhat } \\
\text { superficial and basic skills were } \\
\text { drilled. }\end{array}$ & $\begin{array}{l}\text { Feedback provided by this teacher } \\
\text { was highly mechanical and } \\
\text { concentrated mainly on the } \\
\text { correctness of children's answers. }\end{array}$ & $\begin{array}{l}\text { Highly teacher-driven } \\
\text { conversations that included lots of } \\
\text { repetition and active verbal } \\
\text { modeling. }\end{array}$ \\
\hline Teacher D & $\begin{array}{l}\text { Teacher drilled basic skills nearly } \\
\text { all of the time and proceeded with a } \\
\text { strict plan devised beforehand } \\
\text { without taking children's answers } \\
\text { or previous knowledge into } \\
\text { account. Teacher sometimes used } \\
\text { references to children's daily lives } \\
\text { and familiar things to help them } \\
\text { understand concepts. }\end{array}$ & $\begin{array}{l}\text { Feedback provided by this teacher } \\
\text { was perfunctory and sometimes } \\
\text { ignored children's answers. M ainly, } \\
\text { feedback related to the correctness of } \\
\text { children's answ ers. }\end{array}$ & $\begin{array}{l}\text { Teacher-driven conversations, that } \\
\text { mainly concerned behavioral issues } \\
\text { rather than productive topics. } \\
\text { Teacher verbally model ed the } \\
\text { activities less efficiently than other } \\
\text { teachers. }\end{array}$ \\
\hline
\end{tabular}

